\title{
Patriotism, Rights of Workers and Local Government Autonomy: The Case of Nigeria
}

\author{
Godwin Ihemeje, $\mathrm{PhD}$ \\ Department of Local Government Studies \\ Obafemi Awolowo University, Ile-Ife, Nigeria \\ Email: nedumgod@gmail.com
}

Received: January 22, 2016 Accepted: February 25, 2016 Published: June 01, 2016

doi:10.5296/jpag.v6i2.8914 URL: http://dx.doi.org/10.5296/jpag.v6i2.8914

\begin{abstract}
This paper examines the role of the local government autonomy towards guaranteeing and accelerating the patriotic drive of local government employees. It relies heavily on secondary sources of data collection. The paper argues that Nigerians made up of 1 central (federal); 36 states and 774 local government areas, but mostly confronted with low living standards due to economic hardship among her citizens. Comparatively, the living standards of most local government staffers are nothing to write home about when compared to other levels of government. It recommends appropriate strategies such as principle of federalism, fundamental human rights, constitutional amendment and granting of autonomy to the third level of government.
\end{abstract}

Keywords: Autonomy, Local government, Patriotism, Re-inventing, Workers' rights 


\section{Introduction}

This paper demonstrates that the state of national patriotism and the rights of workers does undermine quality of governance and the "dividends" of democracy presumably expected by all and sundry; however it impacts negatively on the practice of human rights in Nigeria, particularly on Nigerian workers at the local government level, on the hand. Recall that fundamental human rights of workers was trampled upon in high propensity during the military regimes (with the sixteen years of interrupted military rule in Nigeria, 1983-1999) and partly during the 'supposed civilian governments'. A view that corroborates this submission is reported by Mongabay.com (2010), as documented along these lines:

The government's human rights record was mixed and generally worse during military rule, when decrees were exempt from legal challenge. Until late 1970s, when military rulers deprived many citizens of their rights through detention without trial, physical assault, torture, harassment, and intimidation, the issue of human rights was not a major concern, it had been taken for granted that having a bill of rights guaranteed human rights.

In the same vein, Mongabay further stated that the period beginning from Nigeria's independence to early 1970s were marked era of 'innocence' in relation to human rights while the other parts of 1970 s were regarded as the end of 'innocence'.

On the other hand, this paper equally believes that the quality of rights enjoyed by workers determines to a large extent, the way and manner they showcase and popularize their level of patriotism in and outside the country. As such, various views abound on what make patriotism and national identity realistic (Schwind, 2013; National Resistance Movement, 2010).

There is a general consensus that the operators of the Nigerian state have abysmally failed to live up to the hopes and expectations which the Nigerian workers expressed while agitating and supporting the struggle for political and economic independence. It is imperative to therefore state that, Nigerians had yearned, and hope for among other expectations that, self-rule would engender good governance, equal justice, and by extension embrace fundamental rights of workers which would in-turn promote socio-economic and political transformation (Coker and Obo, $2012: 62$ ).

We may argue that, the Nigerian masses whose bulk are partially formed by local government workers are not the sole reason for which the elites demanded for political and economic independence, but are often used to galvanise supports, win votes and attain power and then, dumped afterwards. The response is not farfetched because the moment one becomes a political office holder, his orientation changes and automatically deviates from the mass-public, especially the workers. This perhaps, forms the basis why "Nigeria as a nation is suffering from the spirit of lack of patriotism" (Ogwuonuonu, 2012). Apparently, the efficacy of national patriotism in Nigeria tended not only to consistently grind all efforts to achieving rapid socio-economic and political development of the nation, but also avail several instances where justice, peace, progress, unity as well as prosperity of the country is greatly threatened.

From the foregoing, our aim in this paper is an attempt to bring to fore the inept scenarios of 
national patriotism and workers' rights which have plagued Nigeria, and argue how these have propelled the violations of the basic rights of Nigerian workers, particularly at the local government level. This paper is therefore structured as follows; introduction, concepts of national patriotism, human and workers' rights, local government; experience and lessons from the violation of human rights as applicable to local government workers in Nigeria's Fourth Republic; the place of autonomy as mechanism to reinventing workers' rights, and conclusion.

\section{National Patriotism, Human Rights and Workers' Rights, Local Government: A Conceptual Discourse}

It is germane in this paper to define and explain key concepts used in the study for the purpose of academic clarification and to tackle any form of ambiguity that may arise. This will further aid how the paper is comprehended. Scholarly illustration is documented on the usage of concepts in its appropriate sense and historical orientation (Garba, 2003; Adebanwi, 2010). These scholars frowned against taking concepts for granted as they examined the potency of words and history in the hands of users. To Garba, "the basic tool for the manipulation of reality is the manipulation of words. If you can control words, you can control the people who must use the words" (Garba, 2003:4). Historically, Adebanwi explained that:

if we consider a typical post-colonial state in Africa today, say Nigeria, we can come to the conclusion that our ancestors know good governance more than most contemporary "ruiners" who we call rulers today.

Adebanwi's view is premised on good governance but offering a historical insight which further stresses the need and use of concept in a paper of this nature.

\subsection{Concept of National Patriotism}

In a more democratic experience and contemporary times, the above concept is separately used by writers but that is not to say that they cannot be collectively or mutually use, being an attempt that this paper seeks to demonstrate. For us to achieve a 'national patriotism', we must combine our national pride with a very strong sense of belonging to the country. For instance, American society has a very distinct sense of national identity and open patriotism while Belgians normally identify themselves as "Belgians" only when they are outside of Belgium or talking to a foreigner; but within their country, they tend to identify themselves more frequently as Flemish or Waloon based on their regional or linguistic identity (Schwind, 2013). Since we are talking about 'national patriotism', that means we need to know what each of the connected terms mean because two terms are derivable from the concept; 'nationalism' (national emerges from nationalism) and 'patriotism'.

First, what is nationalism? A good attempt to define nationalism depends on the perspective of the definer and what the definer aims to achieve with it. Nationalism is severally defined on the basis of culture, education, ethnicity language, passion, race, religion and tribe. It is thus possible to speak in terms of cultural nationalism, economic nationalism, ethnic nationalism, linguistic nationalism, literary nationalism, political nationalism, linguistic 
nationalism, primordialism, racialism and religion nationalism (Adekoya, 2006:268).

In a social identity sense, one may equate of nationalism with national identity. By national identity, we refer to a subjective or internalized sense of belonging to the nation and measure it with questions that typically assess social identities (Huddy, 2001; 2003). Within this context, "acts of civil participation are viewed by political theorists as central to national identity in democratic countries and constitute what is seen as normative behaviour for a "good" citizen" (Conover, Searching, and Crewe, 2004). Such a conceptual explanation of nationalism or national identity is widely endorsed and popularized in the United States.

Nationalism can manifest itself in many forms. Hence, Juergenemeyer definition best fits as he asserts that:

Although the term nationalism is sometimes loosely used to describe an attitude of fanatical loyalty to a nation, it also indicates any social philosophy, ideology, or set of shared values that under-guard the concept of nationhood. It refers especially to ideas legitimacy, the secular nation-state that emerged in eighteenth century Europe and America and that emerged and that by the mid - twentieth century had become accepted in most of the modern world(Juergenemeyer,1988: 546).

Nationalism therefore becomes an instrument of liberation as well as that of oppression since its emergence. Just as Adekoya rightly points out that, "nationalism is both a creative and destructive force." A strong feeling, it feeds on shared cultural significance such as skin, colour, and language, myth of origin, racial memory, religion and geographical location to invent a nation.

Some theorists think that it is not a recent phenomenon but a perennial centripetal and centrifugal force that has always brought people together and disperse them ( Adekoya, 2006; Kohn, 2000).

Also Kohn defines nationalism as:

a state of mind. . . an idea, an ideal force which fills man's brain and heart with new thoughts and new sentiments, and drives him to translate his consciousness into deeds of organized $\operatorname{action}($ Kohn, 2000: 64).

In line with Adekoya's submission, nationalism can serve as an instrument of liberation, suppression, discrimination, access and promotion. For instance, most nationals prefer to give consideration to their own nationals or citizens during competitive benefits.

The early nationalism in Nigeria can be described as an organized protest or resistance to foreign rule or colonialism. This was the content in which the key figures known as Nigerian nationalists made use of, in their quest for nationalism as an ideology. Hence, the question is who were Nigerian nationalists? What were their role and backgrounds? It is now pertinent to comment briefly on some of the Nigerian nationalists- Nnamdi Azikiwe, ObafemiAwolowo, Ahmadu Bello etc. Our concern is anchored on their roles in nationalist movement, as documented in brevity, not a detailed history about them. 


\subsubsection{NnamdiAzikiwe (1904-1996)}

He was a native of the present Anambra State. Born in Zungen in Northern Nigeria. His father was a clerk with the Nigerian regiment. He was of Ibo tribe. He studied in Storer College in West Virginia, and later went to Howard and Lincoln Universities. He went to the USA with the money saved by his father and while studying in USA, he did some odd jobs to support himself. On his return to Nigeria he became a foremost nationalist with the establishment of the Zik Press Ltd and founded the West African Pilot. With the Pilot, Zik was concerned about establishing the dignity of Africans and debunkthe fallacy of the myth about the European superiority. He was one of the founding fathers of NCNC, thereby becoming the president and Herbert Macaulay, the secretary general. The problem of the party persisted up till the 1945 general strike. He was the first president of the Federal Republic of Nigeria.

\subsubsection{Ahmadu Bello; Sarduana of Sokoto (1909-1966)}

Born in Sokoto State of North-West, Nigeria. He was educated in Crack Katsina College as well as England. He was a teacher and a Politician. His policies were always on protecting the northerners against the southern domination. He was among the foremost nationalists that fought for Nigerian's independence. He sponsored a counter motion as against Enahoro's motion for self government for Nigeria in 1953. He championed the formation of Northern Peoples' Congress (NPC), just like in the words of Chief S.B Awoniyi "for Sardauna, governance was service to the common man".

\subsubsection{Chief Obafemi Awolowo (1909 -1987)}

Born to an Ikenne farmer in the present day Ogun tate. e had his pre-university education in Nigeria but had his university education in London. A lawyer by profession who became not merely the Yoruba's champion but a politician of a stature, at least equal to Azikiwe's (Walter, 1968: 100). He was one of the key leaders of Action Group (AG), a pre-dominant political party in the west and mid-west between late fifties and early sixties.

Second, what is Patriotism? There exists a broad consensus on the meaning of patriotism as "a deeply-felt and affective attachment to one's own nation with the capacity to make sacrifices for its defence" (Conover and Feldman, 1987:1; Ogwuonuonu, 2012). Enormous discord exist regarding its usage and measurement (Gries et al, 2011; Huddy, 2003; Huddy and Khatib, 2007; Schwind, 2013).

A few definitions are documented. One of such is the one offered by Nathanson, as he defines patriotism as involving the following for attributes:

1. Special affection for one's own country,

2. A sense of personal identification with the country,

3. Special concern for the well-being of the country, and

4. Willingness to sacrifice to promote the country's food (Nathanson, 1993:34-35). 
Again, Patriotism is defined as "a devotion to one's country. A patriot further supports and acts in defense of his or herntry. The term refers generally to a concept of national loyalty. Its derivative is from the Greek word 'patris', meaning fatherland" (Questia, 2013). In the same vein, it is defined as "love someone has for his or her country and willingness to defend it. And a patriot is a person who loves his country and is ready to defend it against an enemy" (Ogwuonuonu, 2012). The definitions appear to capture most essence of belonging to one country or the other, either through parental citizenship or by naturalization saddled with spirit of devotion given to defend any cause of action or inaction about her.

In view of the above, we may then say that national patriotism exist among compatriots of given independent State in pursuing common cause of respect, sacrifice and defense of their fatherland. The love for unity, peace and progress and desire not to disintegrate hallmarks the central idea.

Observing from the various happenings in Nigeria can one vividly say that Nigerians' spirit of patriotism is high? When there is the spirit of patriotism in our country things will get better. Ogwuonuonu once interrogated, where are the patriots who had made sacrifices for the existence of our dear country? Is there any benefit of patriotism in Nigeria? Is Government at all levels, taking note of the efforts of patriots in Nigeria? (Ogwuonuonu, 2012).

\subsection{Concepts of Human and Workers Rights}

Human rights are as old as human beings and have gone through all kinds of review, interpretation and domestications. It has been observed that "human rights as a concept has been constantly evolving and developing through human history" (Shittu, 2012). As such, researchers and historians have always shown it intricately tied to the laws, customs and religions of the people throughout the ages (Shittu, 2012).

Human rights, in its universal view refer to "those rights that are considered universal to humanity, regardless of citizenship, residency status, ethnicity, gender, or other considerations" (Head, 2013). The definition submitted by Amnesty International perceives human rights thus:

Human rights are basic rights and freedoms that all people are entitled to, regardless of nationality, sex, national or ethnic origin, race, religion, language or other status...Human rights are protected and upheld by international and national laws and treaties (Amnesty International, 2013).

In a more comprehensive documentation from Scottish perspective, human rights can be described as:

both civil and political rights to include absolute rights such as the rights to life and freedom from torture, inhuman and degrading treatment, as well as limited rights such as the right to liberty, and qualified rights such as the right to respect for private and family life, home and correspondence. They also include so-called "negative obligations," where the State must refrain from interfering with the exercise of those rights as well as "positive obligations", where the State must take positive steps to ensure the realisation of those rights (SHRC, 
2013:4).

The Scottish definition appears to be elaborate as it specifically stressed the negative and positive obligations of government of States toward enforcing those rights. It further stated that:

there are economic, social and cultural rights; they include workers rights such as rights to social security and rights to take part in cultural life. These rights include immediate obligations such as non-discrimination to prioritise the realisation of "minimum essential levels" of the rights as well as to take effective measures to ensure progressively the full realisation of those rights (SHRC, 2013:4).

Constitutionally, Chapter 4, Articles 33-46 of the Constitution of the Federal Republic of Nigeria (1999) specifically enshrines the fundamental human rights of all Nigerians. These rights as contained in constitution are inalienable rights of Nigerians irrespective of age, sex, class, colour, ethnic-group or religion.

Workers rights are offshoots of human rights because such rights are legally designed by human beings and for humans, not animals or plants. Workers rights are inalienable official or legal rights that employees are expected to enjoy regarding their nature of work. It is important to note that these rights have legal precedence. It is relevant to this paper to point out that Nigerians' right to favourable work conditions are well established in legally obligatory documents that Nigeria as an independent nation is signatory to, such as :

1. Africa (Banjul)Charter on Human and Peoples Rights (Article 15),

2. Convention on the Rights of the Child (Article 32),

3. International Convention on Elimination of All Forms of Racial Discrimination (Article 5(e)(i)),

4. International Covenant on Economic, Social and Cultural Rights (Article 7), and

5. Universal Declaration of Human Rights (Article 23).

The above-mentioned legal bodies were reported by the Nigeria-Human Rights Matrix-Policy Project Group.

Of great concern to our discourse as basis to supporting our argument are items 1,3 , and 5 of the above bodies.

First, the African (Banjul) Charter on Human and People's Rights comprises of four chapters containing sixty-two articles regarding inalienable rights of all Africans. It was unanimously adopted in June 27, 1981 as OAU Document but entered into force in Nigeria on October 21, 1986. Articles $4-15$ are applicable to workers, but emphasis is paid to article 15, which says, "Every individual shall have right to work under equitable and satisfactory conditions, and shall receive equal pay for equal work". The extent to which this agreement has been implemented in Nigeria appears more as a mirage than reality.

Second, Nigeria is a signatory to the International Convention on Economic, Social and 
Cultural Rights. The Convention was adopted and opened for signatory, ratification and assent by General Assembly Resolution 2200A (XXI) of 16 December, 1966. Its adoption entered into law after ten years in Nigeria, on 3 January 1976. In accordance to the Covenant, Part III, Article 7 recognises the right to everyone (especially its members) to the enjoyment of just and favourable conditions of work which ensure, in particular:

(a) Remuneration which provides all workers, as a minimum, with:

(i) Fair wages and equal remuneration for work of equal value without distinction of any kind, in particular women being guaranteed conditions of work not inferior to those enjoyed by men, with equal pay for equal work.

(ii) A decent living for themselves and their families in accordance with the provisions of the present covenant;

(b) Safe and healthy working conditions;

(c) Equal opportunity for everyone to be promoted in his employment to an appropriate higher level, subject to no considerations other than those of seniority and competence;

(d) Rest, leisure and reasonable limitation of working hours and periodic holidays with pay, as well as remuneration for holidays.

Quite a number of conditions mentioned above are not adequately enjoyed by Nigerian workers, particularly at the local government level. What this means is that Nigeria's intention for joining international organisation are not properly articulated and backed by actions. For instance, how many Nigerian workers know their rights, let alone enjoying privileges attached to their jobs?

Third, the General Assembly of the United Nations adopted and proclaimed resolution 217A (III) of 10 December 1948 upon all member countries so as to secure their universal and effective recognition and observance, both among the peoples of member States themselves and among the peoples of territories under their jurisdiction. This resolution is known as Universal Declaration of Human Rights. The Declaration comprises of thirty unperturbed articles, of which Articles 6, 21-26 speak and protect workers' rights, as enshrined therein. Nigeria is equally a signatory to the Declaration but lacks in its proper domestication and applicability.

Given various international treaties that Nigeria is a signatory to, with respect to workers' rights, what calls for worry is that while other member States adopted and implemented the components of those agreements, what Nigeria does is to "adopt agreements and neglect its implementation". That in a way explains the rationale for incessant embark on different kinds of strike by Nigerian workers, at various levels in the past, perhaps due to limitation laws of various states (Shittu, 2012).

\subsection{Concept of Local Government}

The concept are as numerous as people considering its definition, but particular attention are 
often paid to contextualizing the term based on the history, environment, timing, need and politics. However, a number of definitions are perceived useful for the on-going discourse.

The United Nations Office for Public Administration defines local government as:

a political subdivision of a nation or (in a federal system) State, which is constituted by law and has substantial control of local affairs including the powers to impose taxes or to exert labour for prescribed purpose. The governing body of such an entity is elected... (Adamolekun, 1983).

A local government is a political and administrative unit that is empowered by law to administer a specified locality (Answers.com, 2011). Essentially from the definitions, what appear apparent are: that local government is enabled to function based on constitutional strength, and it is saddled to perform prescribed or specific tasks within its territorial jurisdiction.

Another perception of local government can be seen in terms of enhancing development, that is, development-oriented definition as succinctly put forward by Esman and Uphoff:

Local organisations are necessary, if not a sufficient condition for accelerated development which emphasizes improvement in the productivity and welfare of the majority of the rural people(Esman and Uphoff, 1984:29).

There is a definition of local government that gives credence to the idea of decongesting the central (federal) government which is characterized by the regulation of human life and activities, emanating from the view of Belmount as thus:

hedge against undue centralization which might have become dangerous to the liberty or bury the State under the load of an excessive amount of business in the centre. The idea of decongesting the national government is a most practical issue. At an age when the functions of government seem to be expanding and when government is continually being pressed to regulate more and more human life and behaviour ... be it central, intermediate or local (Belmount, 1966:35).

With 774 local government areas in Nigeria, each local government area (LGA) is administered by a local government council consisting of a chairman who is the chief executive of the LGA, and other elected members who are referred to as councillors (Wikipedia, 2011).

In 1991, a major landmark reform was introduced as the system had legislative arm. In addition, the Babagida military administration increased the number of local government from 301 in 1976 to 453 in 1989, and 589 in 1991 while the Abacha regime also increased the number to 774 local councils that we have today and the administrative structure also underwent some changes (Ajayi 2000:71).

The 1999 Constitution provided for a democratically elected local government council in section 7 of the constitution (The 1999 Constitution of Nigeria). Hence, it may be correct to say that the constitution preserves the tripartite system of government at the grassroots level, 
that is, the legislative, executive and judiciary. The legislative functions are meant to perform by the councillors who represent the wards which make up the local government area. The executive powers are vested in the chairman, vice-chairman, supervisor or supervisory councillors, and the entire machinery of local government bureaucracy. The judiciary is streamlined with the federal, state and local government and can avail itself of judicial process available (Awotokun, 2005).

Against this background, it may be difficult to precisely determine the administrative scope of local government councils in Nigeria due to the following reasons:

i. Incessant state and local government creation,

ii. Military to civilian shift of power vis a vis constitutional modifications, and

iii. Functions overlap between state and local government. For example, the erection and maintenance of bill boards, roads, and collection of taxes.

\section{Experience and Lessons from the Violation of Human Rights as Applicable to Local Government Workers in Nigeria: The Case of Fourth Republic}

In this section of the paper, attempts are made to examine the various experiences of workers in Nigeria with respect to the violation of rights, the role of the Nigeria Labour Congress, how the local government workers have responded to the deprivation or negligence of those rights.

First, it has been revealed that in Nigeria, workers' rights to personal dignity and safety is not only precarious but not guaranteed, as observed in the quotation below:

Violence against trade unionists is endemic, including murder, disappearance, intimidation, torture, harassment, and detention. In 2002, shortly after Nigerian Labour Congress (NLC) declared a nation-wide strike over the increase of petroleum prices, security agents rounded up Adams Oshiomole, the NLC president (now, the Governor of Edo State) and several other labour leaders, including Dr.DipoFashina, president of the Academic Staff Union of Universities (ASUU). Sixteen other union leaders were arrested in Port Harcourt, Rivers State; while twenty-five persons, including the state secretary of NLC, Wale Olaniyan were locked in Ogun State by the police. In the course of the Abuja arrests, the police exhibited excessive brutality. They seized the NLC president's car and savagely beat up Dare Agbaje, the driver. ASUU president, Fashina had its shirt turn and one of his fingers broken. Throughout a twenty-four hour stint in detention, they were not allowed to receive medical attention (CDHR, 2002:131).

The above view was unhealthy molestation and infringement of rights among the Nigerian workers during the military rule, who were majorly union leaders.

In addition, it has been reported that there was an incidence in "February 2008, of police killing more than 50 persons in Ogaminana, Kogi State; police reportedly attacked the village for reprisal over the killing of a Colleague by local youths" (U.S. Department of State, 2012). Worthy of note, in a situation when police who are to maintain law and order, protect lives 
and properties of citizens deliberately, not inadvertently, terminate people's lives vividly explains the level of lawlessness that exist among the law enforcement agency who are the 'supposed friend of people'.

In the same vein, it has been established of the brutality, assaults and even killings of civilians who were mainly local government workers in Plateau State, as documented thus:

In the investigation conducted in Plateau State on November 2008, security forces killed approximately 700 civilians in the Jos North local government area being attributed to provocation and crisis by religious leaders as well as by political parties and local government officials (U.S. Department of State, 2012).

The occasioned killings of 700 civilians is a huge loss to the nation at large but, what insinuations can be deduced from such experience when Nigeria is said to be a democratic State? This expression clearly explains how workers rights have been adversely trampled upon, even to the point of 'taking their lives'. This paper alludes that "an injustices done to workers is an injustice to all," because the Nigerian workers form a formidable force that make policies for the nation while at the same time responsible to many families.

Second, what attempt has been made to rescuing workers from undue truncation, deprivation or neglect of rights? Interestingly the role of Nigerian Labour Congress becomes very germane and relevant in this regard, as asserted:

As a workers' organisation, it is understandable that NLC has over the years protected, defended and deepened workers' rights. These efforts have covered not only the rights of workers in the work place but also their rights in the larger society. Part of these strategies deployed by NLC has included the education of large numbers of its leadership, established, established Harmattan and Rain Schools, mobilised its 28 affiliates and 37 State councils to picket First Bank in 2002. This informs the contributions of NLC to the formation of Labour Party in Ondo State, (at the instance) the struggle for workers to have the right to participate in certain governance decision making structures (Iyayi, 2008).

Beyond Iyayi's position is to state that the important contribution of NLC towards achieving the rights of workers cannot be under-estimated at all levels (Alalade, 2004; Alubo, 2007). NLC have always collaborated with ASUU to achieving its demands. For instance, the then labour leader, Adams Oshiomole representing Labour Union was instrumental to the implementation of certain parts of the 2009 Federal Government and ASUU Agreements which include among other things, increased minimum wage/salaries, 70 years as retirement age for professors and profession of infrastructures. Another achievement of the NLC include the national wage increase of workers, that is the minimum wage increase, defeat of government's initial position to take loan from World Bank/IMF, opposition to various military rules, collaboration and alliances with ASUU and NANS (Alubo, 2007; Iyayi, 2008).

Third, in its explicative form we attempt to report scholarly perceptions on the nature of the local government workers whose rights have been hitherto remained comatose (Ananti and Umeifekwam, 2012; Ezeani, 2004; Ikejiani Clark and Ezeh, 2009; Ogunna, 2007). These perceptions range from poor work ethics, low productivity, and corruption. In response to the 
poor conditions of work one endeavours to determine reactions essentially from the local government workers.

Among the three levels of government in Nigeria (Federal, State, Local), it is at the local government level that salaries, wages and other allowances paid are found to be abysmally low (Ananti and Umeifekwam, 2012:388), that may be the reason why they engage in other businesses to support their low earnings because of the high inflation rates in the country.

The employees of the Nigerian local government system are believed to have poor work ethics with some reasons which range from economic, sociological, managerial and technological factors (Ikejiiani Clark and Ezeh, 2009). The argument put forward by these scholars is premised on the fact that the local government workers in Nigeria waste resources, both human and material without achieving desired result. Arising from Ikejiani Clark and Ezeh' argument is the question of how many resources that are made available for these workers to improve their job proficiencies? However, we may be quick to respond that the denial, deprivation and poor conditions to service are attributed to be responsible for poor productivity at that level. This response is strongly corroborated in another writing that offers factors that aid productivity:

productivity in any organization is dependent on a number of factors such as the use of appropriate technology, adequate motivation, adequate resources which includes optimum use of fund, materials and personnel, and positive work ethics, professional and technical competence of workers (Ogunna, 2007).

It may be deduced therefore that local government workers in Nigeria are confronted with challenges that range from poor motivation, lack of adequate fund in connection to remunerations as well as high corruption rate among officials, and politicised nature of recruitment. These challenges (can also be seen as factors) may be further classified into internal and external. Either classified as internal factors or external ones, the emphasis is anchored on the fact that these factors render the local government workers as misfits because their fundamental human rights (workers' rights) as tied to their working conditions are trampled upon or denied them, in most cases.

Apart from the issue of low productivity comes the corruptive perception of the local government workers. It has been observed that corruption and embezzlement of funds is responsible for the deprivation of local government workers to enjoy their rights. This view is explained along these lines:

Corruption in the form of fraud and embezzlement of funds have been responsible for the failure of some local government councils in Nigeria to execute some developmental projects for the people and sometimes unable to pay staff salaries (Ezeani, 2004).

Corruption of this nature may to a very large extent, impede further agitation for better working conditions for these employees at the grass-roots. We may also add, that the negative attitudes of workers at the third level of government retards the effort of both the Federal and State governments to provide the basic needs of the Nigerian masses in the rural areas (AnantiandUmeifekwem, 2012: 387). These negative attitudes include lateness to work, 
absenteeism, indiscipline among local government officials, and partisan politics.

\section{The Place of Autonomy as a Mechanism to Re-inventing Workers' Rights at the Local Government Level}

The main position of this paper presupposes that local government workers cannot enjoy equal rights with their counterparts at the State and Federal levels on the ground that local government is yet to be an independent body, of which such agitation for it to be independent is about forty years now (as at the period of compiling this paper), between 1976 local government reforms that resulted into a single-tier level and 2016, yet the local government is, in calculative terms, a mere appendage in the hands of both the State and Federal governments in Nigeria, hence the need for autonomy.

This problem of autonomy is partly politics and partly constitutional if one takes a careful study on the 1979 and 1999 constitutions of the Federal Republic of Nigeria. Most politicians were keen to exploit this lacuna for political 'cheap goals' while constitutional provisions for the State controlled local government service board, a JSLGA (Joint State Local Government Administration) and State oversight functions undermined the autonomy of local government (Ukiwo, 2006). Associated with autonomy are other suggestions that can assist in re-inventing the local government workforce such as principle of federalism, constitutional provision and granting of autonomy.

\section{Recommendation}

The suggestions proffered as way forwards emanated basically from federalism orientation because Nigeria is said to practice 'federal system' of government, however such derivable suggestions hover around the term "autonomy."

\subsection{Principle of Federalism}

There is a high degree of consensus among scholars regarding the principles of federalism (Campagnani, 1996, Wheare, 1963; Friedrich, 1963, Gboyega, 1993; Amuwo, 1998, Hatch and Herbert, 2010). Federal principle has been defined thus:

...federal principle in all federal constitutions is underpinned by the existence of two areas equipped with same autonomy, the federal Government and Governments State (Campagnani, 1996).

Based on the above scholar's view, there is an overwhelming support for autonomy given to the component unit of government, that is "local government.". Autonomy is one of the principles of federalism while others include constitutionalism, separation of powers, accountability and responsive governance (Gboyega, 1993; Amuwo, 1998; Ariyo, 2003). In essence, federalism as correctly put, "is not an optional practice but a constitutional imperative with fundamental limitation on government power" (Hatch and Herbert, 2010). For Nigerian local government workers to enjoy their rights there must be strict adherence to the practice and principles associated with federalism by Nigerian government. 


\subsection{Constitutional Provision}

Recall, the guidelines of the 1976 LG reforms started the autonomy of local governments when the documented stated that 'membership of Local Government Councils should be predominantly elected either by direct or indirect lections from local communities... (Nigeria, 1976). This recurring but 'non-granted autonomy' was enshrined into the 1979, 1989, and 1999 Nigerian Constitutions, while specifically section 7 of these constitutions stressed, ' a system of local government by democratically elected local government is under the constitution guaranteed'. The constitution is apparently silent about given full autonomy to the third tier of government. In list of functions as contained in constitution, the local government appear to have too many overlapping functions with the State government. So this can be better addressed in the intending constitutional review or amendments. Apart from that, the local government workers are bona fide citizens and therefore should enjoy similar rights like their counterparts in the State and Federal services because they are already defined by constitution as citizens.

\subsection{Granting of Autonomy}

By 'autonomy', we mean having some degree of freedom and independence to exercise certain functions within a defined jurisdiction. That is to say, local government areas in Nigeria deserve such independence so as to allow their workers better able to drive home demands, particularly those that bother on working conditions, workers' rights. For it to be effective, it requires the backing of the law.

\section{Conclusion}

It is pertinent to bring to fore that the Nigerian Constitution does not specifically provide for autonomy as a full constitutional right for the third tier of government as obtainable in the United States of America, but it is hoped that provisions which by implication affects the institutionalization of local government workers' rights and those that support the concept of autonomy as a principle of federalism should be incorporated into the constitution as it is been reviewed. Not only that, the various international human rights and the relevant instruments should be well domesticated to give the local government workers equal opportunity to have their rights better guaranteed.

However, the scenario of local government areas and their teaming workforce being perceived to have deepened corruption, suffering and lack of motivation instead of ensuring that development gets closer to the people debars dividends of democracy to be felt at the grass-roots. Note that each level of government has got its own peculiar problem but what is more important is to ensure how synergy between the fundamental human rights and workers rights can become realistic at the local level. Although it is assumed that granting of autonomy will catalyse the process of achieving worker's rights, but the question is, for long will these workers continue to wait for autonomy so as to enjoy their lawful rights?

\section{References}

Adamolekun, L. (1983). Public Administration: A Nigerian and Comparative 
Perspective. New York: Longman Inc.

Adebanwi, W. (2010).Avudwene in Abuja', The News, May 17.

Adekoya, O. (2006). Literature and nationalism: The Example of Soyinka. In theHumanitarian Nationalism and Democracy, Akinrinade, S., Fashina, D. Ogungbile, O.D. (eds), Cedur Publication.

Ajayi, K. (2000). Theory and practice, Ado Ekiti: UNAD.

Alalade, F.O. (2004). Trade unions and democratic option in Nigeria. Journal of Social Sciences. Vol. 9. No. 3 Pp.201-206

Alubo, S.O. (2007). Fueling the crisis: labour, the state and pump price increase in Nigeria. A commissioned research paper. Nigeria Labour Congress, October. Amnesty International USA (2013). Human rights basics.http://www.amnestyusa.org/research/human-rights-basics(Accessed 19/04/2015).

Amuwo, K. (1998). Nigerian Federalism in Historical Perspective.Ibadan: Spectrum Books.

Ananti, M.O. \&Umeifekwem, U. (2012). Work ethics and productivity in local government system in Nigeria: problems and prospects. African Research Review.Vol.6 (1), Serial No 24, January, http://dx.doiorg/10.4314/afrev.v6il.30 (Accessed, 19/12/2015).

Answers. Com (2011). What is the origin of local government council in Nigeria.file.///C:

/Users/nedum/Downloads/local Govt 5 html (Accessed 15/12/2015).

Ariyo, A. (2003). Theories of federalism. Paper presented at Ad-Hoc Expert Group Meeting, Addis Ababa: Economic Commission for Africa. 7-9 October.

Awotokun, K. (2005). Local government administration under 1999 constitution in Nigeria.

Journal of Social Sciences, 10 (2).

Belmount, J. E. (1966). An ancient partnership: local government Magna Carta and national interest. Chalottesville.

Campagnani, M. (1996). Coordinator, federalismoslatinamericanos: Mexico, Brazil, Argentina, FideicomisoHistoriadelas Americas- El ColegiodeMexicoy Fundo

De Culture-Economics. Mexico.

Coker, M.A. \& Obo, U.B. (2012). Crisis of governance and the violations of human rights: the Nigerian experience, 1999 to 2007. African Journal of Political Science and International Relations.

Committee for the Defence of Human Rights [CDHR] (2002). Annual report on the human rights situation in Nigeria. CDHR Nigeria, Pp.131.

Conover, P.J. \& Feldman, S. (1987). Memo to NES board of overseers regarding measuring patriotism and nationalism.http://www.icpsr.umich.edu 


\section{Ml Macrothink}

Journal of Public Administration and Governance ISSN 2161-7104

Conover, P. J., Searing, D.D. \& Crewe, I. (2004). The elusive ideal of equal citizenship: political theory and political psychology in the United States and Great Britain. Journal of Politics 66(4): 1036-1068.

Esman, M.J. \&Uphoff, M.T. (1984).Local organisations: intermediaries in rural development. Ithaca: Cornell University Press.

Ezeani, E.O. (2004). Local Government Administration.Enugu: Zik-Chuks Press.

Friederick, C. (1963). Federalism and opposition: trends of federalism in theory and practice. In Peter Rogers (ed.). Trends of federalism in theoryand practice.London: Pall Mall Press.

Garba, A.G. (2003). Introduction: the past, present and possible futures of Africa. In Abdul-Ganiyu, ed, Development Thought, Policy Advice and Economic Development in Africa in the $20^{\text {th }}$ Century: Lessons for the $21^{\text {st }}$ Century. Ibadan: Ibadan University Press.

Gboyega, A. (1993).Local Government Reform in Nigeria.In Phillip Mawhood (ed), Local government in the third world: experience of decentralization in Tropical Africa. South Africa: Africa Institute of South Africa.

Gries, P.H., Zhang, Q., Crowson, H. M. \&Cai, H. (2011). Patriotism, nationalism and China's US policy: structures and consequences of Chinese national identity. The China Quarterly, 205, Pp. 1-17.

Hatch, O. \& Herbert, G. (2010). My view: federalism must not be abandoned. Deseret News.

Head, T. (2013). Definition: human rights.

http://www.civilliberty.about.com/od/international human rights/g/Human-Rights. Definition.html. (Accessed, 20/11/2015).

Huddy, L. (2001). From social to political identity: a critical examination of social identity theory. Political Psychology 22(1): 127-56.

Huddy, L. (2003).Group membership, in-group loyalty and political cohesion. In David, O. Sears, L. Huddy, \&R. Jervis eds, handbook of political psychology. New York: Oxford University Press. Pp. 511-58.

Huddy, L. and Khatib, N. (2007). American patriotism, national identity and political involvement. American Journal of Political Science.Vol. 51 No 1. January, Pp. 63-77.

Ikejiani, M.C. \&Ezeh, C. (2009). Human capital development utilization and challenges of productivity in the Nigerian local government system: Enugu State experience. In O.S.A. Obikeze, A. Akamobi, C. Nwanegbo, C. Nwabueze (eds), Dynamics of Public Sector Management in Nigeria.

Juergenemeyer, M. (1988).Nationalism: the encyclopaedia of politics and Religion.London: Rutledge, Vol. II, Pp. 546-551.

Kohn, H. (2000). The idea of nationalism. In Hutchinson, J. \& Smith, A. D. (eds), Nationalism: Critical Concepts in Political Science. London and New York: Rutledge. Pp. 64-68. 
Mongabay.com (2010). Nigeria-human rights-

Nigeria Index, $\quad$ http://www.mongabay.com./history/Nigeria/Nigeria-human-rights.html (Accessed 17/12/2015).

Nathanson, S. (1993).Patriotism, morality and peace. Lanham: Rowman \& Littlefield National Resistant Movement (2010). Patriotism and the promotion of national interest and common good. http://www.nrm.ug/manifesto-and-internationalrelations-o. (Accessed 17/10/2015).

Nigeria, Federal Republic 1976 Guidelines for Local Government Reform, Kaduna: Government Printer. Nigeria-Human Rights Matrix-Policy Project/ Futures

Group.http://www.policyproject.com/matrix/matrix2.cfm?country=Nigeria

(Accessed 21/10/2015).

Ogunna, A.E.C. (2007).Basic issues in community development and local government. Owerri: Versatile Publishers.

Ogwuonuonu, F. E. (2012). Opinion: why the spirit of patriotism is low in Nigeria.National Network for Perfect Truth.Vol. 9, No. 17, May 2-8.

QuestiaTrusted Online Research (2013). Patriotism.http:www.questia.com/library/ politics-and-government/political-science/political-movements/patriotism

(Accessed, 20/11/2015).

Schwind, S. (2013). An American's view of national identity and patriotism in Europe. United States of America: German Marshal Fund of the United States.

Shittu, W. (2012). Fundamental rights enforcement procedure rules and limitation laws. Punch Newspaper, February 13, http://www.puncing.com/feature/the-law-you/fundamental-rights-enforcement-procedure-rule s-and-limitation (Accessed 18/11/2015).

The Constitution of the Federal Republic of Nigeria, 1979.

The Constitution of the Federal Republic of Nigeria, 1999.

The Scottish Human Rights Commission (2013).The future of human rights in Scotland. http://www-scottishhumanrights.com/news./latestnews/article/futscotpaper2013(Accessed, 20/11/2015).

Ukiwo, U. (2006). Creation of local government areas and ethnic conflicts in Nigeria: The Case of Warri, Delta State. Accra: A draft paper presented at the CRISE West Africa Workshop. March

U.S. Department of State (2012).2011 human rights reports: Nigeria.

http://www/state-gov/j/drl/rls/hrrrpt/2011/af/186229.html (Accessed, 24/11/2015).

Walter, S. (1968). Nigeria. New York \& London: PragerPublishers. 


\section{Macrothink}

Journal of Public Administration and Governance ISSN 2161-7104 2016, Vol. 6, No. 2

Wheare, K. C. (1963). Federal Government, $4^{\text {th }}$ edition. London: Oxford University Press.

\section{Copyright Disclaimer}

Copyright for this article is retained by the author(s), with first publication rights granted to the journal.

This is an open-access article distributed under the terms and conditions of the Creative Commons Attribution license (http://creativecommons.org/licenses/by/3.0/). 